\title{
APOC1 wt Allele
}

National Cancer Institute

\section{Source}

National Cancer Institute. APOC1 wt Allele. NCI Thesaurus. Code C138109.

Human APOC1 wild-type allele is located in the vicinity of $19 q 13.32$ and is approximately 5 $\mathrm{kb}$ in length. This allele, which encodes apolipoprotein C-I protein, plays a role in the metabolism and transport of lipids. 